This item was submitted to Loughborough's Research Repository by the author.

Items in Figshare are protected by copyright, with all rights reserved, unless otherwise indicated.

\title{
Improving on-plot sanitation management in low-income settlements of cities of developing countries: case study from Maputo, Mozambique
}

PLEASE CITE THE PUBLISHED VERSION

http://dx.doi.org/10.1504/IJEWM.2015.071287

\section{PUBLISHER}

(C) Inderscience

\section{VERSION}

AM (Accepted Manuscript)

\section{PUBLISHER STATEMENT}

This work is made available according to the conditions of the Creative Commons Attribution-NonCommercialNoDerivatives 4.0 International (CC BY-NC-ND 4.0) licence. Full details of this licence are available at: https://creativecommons.org/licenses/by-nc-nd/4.0/

\section{LICENCE}

CC BY-NC-ND 4.0

\section{REPOSITORY RECORD}

Kayaga, Sam, Amaka O. Godfrey, Andrew P. Cotton, and Carla Costa. 2019. "Improving On-plot Sanitation Management in Low-income Settlements of Cities of Developing Countries: Case Study from Maputo, Mozambique". figshare. https://hdl.handle.net/2134/17757. 
Improving on-plot sanitation management in low-income settlements of cities of developing countries: case study from Maputo, Mozambique.

\begin{abstract}
Whereas water service coverage in urban areas of developing countries was estimated at $94 \%$ of the urban population in 2011 , coverage for sanitation services was much lower, estimated at $74 \%$. This paper reports on the sanitation situation in Maputo's low-income settlements, and highlights the important role played by nonstate actors in providing solid waste management (SWM) and faecal sludge management (FSM) services to most residents of Maputo's low-income settlements. Data were collected in 2011, through analysis of policy/ project documents, semistructured interviews with key stakeholders, and observations in three neighbourhoods. While SWM services in Maputo have tremendously improved, there are huge service gaps in emptying, transporting and disposing of faecal sludge from pit-latrines, the most dominant sanitation facility in Maputo. There is need to create a conducive environment for more effective engagement with non-state actors so as to scale up delivery of FSM services. Lessons from SWM can be adapted for FSM in Maputo and cities of other developing countries.
\end{abstract}

Key words: faecal sludge management, institutions, low-income settlements, Mozambique, non-state providers, public-private partnerships, urban

\title{
1. INTRODUCTION AND BACKGROUND TO THE STUDY
}

Countries of developing regions are unavoidably becoming more urbanised. According to projections of 2011 UN-HABITAT's global report on human settlements, about 55\% of people in the developing countries will live in urban areas by 2030 (UN-HABITAT, 2011). However, the population increase in cities and towns of most developing countries is absorbed by low-income urban settlements or slums. A slum household is defined as a group of individuals living under the same roof, in deprivation of basic infrastructure services such as improved sanitation, basic piped water supply, sufficient living area, and security of tenure (UN-HABITAT, 2003). Although the proportion of the urban population living in slums of cities in the world's developing regions declined from $39.4 \%$ to $32.6 \%$ during $2000-2010$, the absolute numbers of slum dwellers actually increased from 770 million to 840 million in the same period (UN-HABITAT, 2013). Hence, providers of infrastructural services such as water, sanitation and roads will continue to experience challenges to overcome the physical, technical, economic, institutional and legal constraints encountered in extending services to the escalating informal, high-density and often unplanned settlements (Kayaga, 2013).

The most recent report of WHO/ UNICEF J oint Monitoring Programme shows the developing regions of the world have improved the urban populations' access to improved water supplies from 88\% in 1990 to $94 \%$ in 2011. Also, the proportion of people in urban areas of developing countries with access to improved sanitation 
facilities improved from 65\% in 1990 to $74 \%$ in 2011 . Improved sanitation facilities are described as those are likely to ensure hygienic separation of human excreta from human contact. They include flush/ pour flush to piped sewer system, septic tank or pit latrine; ventilated improved pit (VIP) latrine; pit latrine with slab; and composting toilets (WHO/UNICEF, 2013). Only a small percentage ( $<5 \%)$ of households in developing countries is connected to sewerage networks (Baum et al, 2013). In absolute terms, the number of urban dwellers in developing countries without access to private improved sanitation facilities was estimated at 682 million. The situation is worse in sub-Saharan Africa, where about 456 million people, over half of urban dwellers, rely on unimproved sanitation facilities [26\%], or practice open defecation [26\%]) (WHO/ UNIUCEF, 2013). Some scholars have identified constraints to providing effective urban sanitation services in urban areas of developing countries, many of which are related to urban governance. Examples are (Murungi and van Dijk, 2014): failure by governments to effectively respond to the sanitation crisis; institutional fragmentation and poor coordination among relevant government agencies; lack of legislative capacity to perform duties; and lack of accountability on the part of the political leaders. However, the situation also presents huge challenges for professionals in the sanitation sector, and calls for innovative approaches.

In the recent past, various scholars have analysed the root cause of poor performance of the urban sanitation sector in developing countries, particularly in sub-Saharan Africa. Some scholars (e.g. Tilley et al, 2013; Leach et al, 2010) have argued that traditionally, providing sanitation services has primarily been considered a technical problem that requires an engineering solution; hence engineers have been the main actors. This model has worked quite well in developed countries where national economies have financial and institutional capacities to construct, operate and maintain conventional sewerage and sewage disposal systems. However, the same model has not worked well in developing countries which rely on on-plot sanitation services for most households. Evaluations of most sanitation projects and programmes point to challenges related to cultural constraints, difficulties in securing behavioural change, lack of political support, or low capacity to carry out operation and maintenance of the sanitation facilities (World Bank, 2003). On-plot sanitation is further complicated by issues concerned with tenure security versus affordability and willingness to spend on capital and operational costs (Scott et al, 2013).

To overcome these constraints, professionals in the sanitation sector are increasingly realising that there is a need to have multi-disciplinary approaches to planning, design, construction, operation and management of on-plot sanitation facilities. Technocratic-leaning approaches often lack critical connections with the socioeconomic reality of the existing situation (Tiberghien et al, 2011). Recent research has shown that there is still tension within the sanitation sector between rhetoric for community-based and participatory approaches and conformity to rational- 
comprehensive approaches to planning, which require achievement of strict engineering standards and norms (McConville, et al, 2011).

To achieve the post-2015 targets for sanitation and hygiene services, the water and sanitation sector professionals in developing countries will have to get out of their comfort zones, so as to convert opportunities in the operating environment into strengths, and minimise the effects of existing threats, in order to provide sustainable services. One of the existing opportunities in many cities of developing countries is the emergence of small-scale local entrepreneurs, with whom professionals in the sanitation sector can create effective partnership for providing sanitation services. A partnership is a strategic alliance, with partners complementing each other's strengths, and aligning their resources so that they can contribute specific aspects, which enable all involved to achieve mutually recognised and agreed objectives (Taing et al, 2013). For these partnerships to be effective there must be an enabling environment that provides policy guidance, rules, and incentives for motivating stakeholders to prioritize sanitation, ensure accountability, and develop adequate levels of capacity for delivering the necessary services sustainably and affordably (WSP, 2013).

This paper is based on data collected in 2011/ 2012, as part of a multi-country study sponsored by the Bill and Melinda Gates Foundation, and carried out in Burkina Faso, Cameroon, Ghana, Kenya, Mozambique, and Senegal (WSA, 2012). The specific objective of this paper is to highlight the extent to which non-state providers are contributing to the delivery of sanitation services in the low-income informal settlements of urban areas of developing countries, using Maputo as a case study, and recommend for constructive engagement with these providers, through institutionalized public-private partnerships.

This paper highlights the existing involvement and interest of non-state providers in providing solid waste management (SWM) and faecal sludge management (FSM) services in low-income settlements of Maputo, Mozambique's capital city, as an important opportunity which policy makers and managers of the sanitation sector need to tap into so as to improve the services. The scope of this paper is limited to the primary collection stage of SWM; and, with respect to on-plot sanitation, to the collection and transportation of faecal sludge. The next section describes data collection methods. Thereafter, the results and their discussion are presented. We then conclude by listing key lessons that could be adapted from implementation of a public-private partnership programme for primary collection of solid wastes implemented since 2002, which has resulted in improved SWM services in Maputo.

\section{MATERIAL AND METHODS}

This study utilized a case study methodology, for which we obtained approval from Loughborough University's Ethics Approvals (Human Participants) Sub-Committee . The data reported in this paper are with respect to the case of Maputo, Mozambique. Consultations were made with two key organisations involved in sanitation in 
Maputo, i.e. Water and Sanitation for the Urban Poor (WSUP), an international development agency that was at the time carrying out a capacity development programme for service providers; and the Water and Sanitation Program (WSP) of the World Bank, to select field study sites, which represented typical activities in urban sanitation, and provided a good geographical representation. Data were collected from three low-income settlements of Maputo, i.e. the bairros (sub-districts) of Maxaquene A, Chamnaculo B. and Urbanizacao.

- Data collection tools were designed, pre-tested and discussed in a workshop attended by the research consortium members. This improved the validity and reliability of the data collection tools. Also, the research was designed such that there could be triangulation of multiple data sources, participation of three researchers and multiple data collection methods. The data collection methods included: Study and analysis of government policy documents and project reports of international development agencies;

- Observations in the case study areas; and

- Semi-structured interviews with 43 stakeholders involved in service provisions in the study areas.

Interviews were held with representatives of relevant government departments, international development agencies, service providers, local leaders and various categories of users. We purposefully selected two households living near a water point, in each of the three bairros, so as to obtain a snapshot of household perceptions of the services. We also talked to two traditional emptiers, whom we made contact with through WSUP. At the time of the study, no formal organisation of traditional pit-latrine emptiers existed. However, an informal group of the tradition pit-latrines empties was in place, as part of a process started by WSUP to assist in the organisation and formalisation of the group. We were unable to interview wastewater/ faecal sludge treatment plant operators as planned, because the plant was unattended on three occasions we visited it. Annex 1 shows the interview guide used for engaging with the traditional pit-latrine emptiers.

The fieldwork was carried out during the period 25J uly 2011 to 5 August 2011. Table 1 shows the range of key stakeholders interviewed. Descriptions and roles of the various stakeholders have been provided in sub-sections 3.2 and 3.3.

Table 1: Key stakeholders interviewed

\begin{tabular}{|c|c|}
\hline Category & Key Informant(s) \\
\hline \multirow[t]{3}{*}{$\begin{array}{l}\text { Government } \\
\text { agencies }\end{array}$} & $\begin{array}{l}\text { Maputo City Municipal Council: } \\
\text { - Head, Departmento de Agua e Saneamento (DAS), i.e. Department of } \\
\text { Water and Sanitation }(n=1) \\
\text { - } \quad \text { Senior Engineer, DAS }(n=1)\end{array}$ \\
\hline & $\begin{array}{l}\text { Central Government: } \\
\text { - Head, Direcção Nacional de Águas (DNA), i.e. National Water } \\
\text { Directorate }(\mathrm{n}=1) \\
\text { - } \text { Head, Administraco de Infra-estruiras Abastecimento de Agua e } \\
\text { Saneamento (AIAS), i.e. Water and Sanitation Infrastructure } \\
\text { Administration }(\mathrm{n}=1)\end{array}$ \\
\hline & $\begin{array}{l}\text { Conselho de Regulacao de Agua (CRA), i.e. the Water Regulatory Board : } \\
\text { - } \quad \text { President }(n=1)\end{array}$ \\
\hline
\end{tabular}




\begin{tabular}{|c|c|}
\hline Category & Key Informant(s) \\
\hline & - $\quad$ Economist $(\mathrm{n}=1)$ \\
\hline $\begin{array}{l}\text { International } \\
\text { NGOs }\end{array}$ & $\begin{array}{l}\text { - } \quad \text { Country Team Leader, World Bank-Water and Sanitation Program } \\
\text { (WSP) }(\mathrm{n}=1) \\
\text { - } \quad \text { Country Manager \& key staff, WSUP }(\mathrm{n}=1) \\
\text { - } \quad \text { Field staff, Water Aid }(\mathrm{n}=1)\end{array}$ \\
\hline \multirow[t]{2}{*}{$\begin{array}{l}\text { Service } \\
\text { providers }\end{array}$} & $\begin{array}{l}\text { Private operators: } \\
\text { - Founder and Chief Executive Officer, Uaene Gama de Serviços de } \\
\text { Maputo Lda (UGSM) }(\mathrm{n}=1) \\
\text { - } \quad \text { Traditional emptiers }(\mathrm{n}=2) \\
\text { - Sanitation block operators }(\mathrm{n}=3)\end{array}$ \\
\hline & $\begin{array}{l}\text { Community-Based Organisations (CBOs): } \\
\text { - Committee members of Associação da Desenvolvimento da Agua e } \\
\text { - } \text { Saneamento do Bairro de Urbanização (ADASBU) }(n=6) \\
\text { Committee members of XIVONINGO }(n=3)\end{array}$ \\
\hline \multirow[t]{2}{*}{$\begin{array}{l}\text { Local leaders } \\
\text { and users }\end{array}$} & $\begin{array}{l}\text { Local leaders: } \\
\text { - Secretary of bairro }(n=1) \\
\text { - President, Commission on WS\&S of bairro Consultative Council }(n=1) \\
\text { - } \quad \text { Shief of Quarter }(n=1) \\
\text { Sanitation block committee members }(n=4)\end{array}$ \\
\hline & $\begin{array}{cl}\text { Users: } & \\
\text { - Heads of households using septic tanks }(n=2) \\
\text { - Heads of households using communal sanitation blocks }(n=4) \\
\text { - Heads of households using traditional latrine }(n=2) \\
\text { - Heads of households with improved pit latrines }(n=4)\end{array}$ \\
\hline
\end{tabular}

\section{RESULTS AND DISCUSSION}

\subsection{The study setting}

Mozambique's population was estimated at 23.4 million in 2010, and is projected to increase to 29.2 million by 2020 . About $30 \%$ of the people live in urban areas, most of whom (over 80\%) reside in slums (UN-HABITAT, 2013). UN-HABITAT estimates that Conselho Municipal de Maputo (CMM), i.e. Maputo City Municipal Council, the administrative and commercial capital of Mozambique, is home to about 1.132 million people, which equates to $15 \%$ of the country's urban population (ibid).

CMM is administratively demarcated into seven municipal districts, and each district is further sub-divided into several sub-districts known as bairros. The bairro is an administrative unit under the local government system in urban areas of Mozambique, headed by the Secretary of the bairro, who is largely an administrative leader, although he/ she is elected by residents. There are a total of 54 bairros in CMM. The bairros are further demarcated into quarteirões (i.e. quarters), made up of several tens of households. About 1.056 million people live in bairros which amounts to over $90 \%$ of Maputo City's population (WSUP, 2011). Table 2 shows the demographic characteristics of the bairros where primary data was collected. 
Table 2: Demographic characteristics of the case study areas $(2011)^{\dagger}$

\begin{tabular}{|l|c|c|}
\hline & Estimated Current Population & No. of households \\
\hline Maxaquene A & 25,060 & 3058 \\
\hline Chamnaculo B & 27,000 & 5,200 \\
\hline Urbanizacao & 15,793 & 3,297 \\
\hline
\end{tabular}

According to the WHO/ UNICEF J oint Monitoring Programme (2013), the national service coverage for use of improved drinking water sources was estimated at $47 \%$ in 2011. Although the overall improved water service coverage in Mozambique's urban areas is much higher, estimated at 78\%, only $19 \%$ of urban residents have access to on-plot piped water services. The proportion of the country's population using improved sanitation facilities is much less: only 19\% of Mozambique's population have access to improved, unshared sanitation facilities. The coverage is higher in the urban areas, with $41 \%$ of the residents using improved, unshared sanitation facilities (WHO/ UNICEF J oint Monitoring Programme, 2013).

On-site sanitation facilities are used by the majority of residents in the City of Maputo, who live in high-density, informal, unplanned settlements. The Mozambique Multiple Indicator Cluster Survey of 2008 estimated that flushing toilets (connected to the central sewerage system and septic tanks) serve about $14 \%$ of the population in Maputo, while about $40 \%$ are served by improved latrines. The rest of the population either rely on unimproved latrines or have no defined sanitation facilities and are thought to be using open defecation (WSUP and SEED, 2011). The sewerage system in Maputo was originally designed for a much smaller population living in downtown Maputo, and has not been expanded in tandem with the city's urbanization rate, estimated at about 3\% per year (UN-HABITAT, 2013).

Pit latrines are the most common type of sanitation in these informal settlements. Results of a survey study carried out by CMM in 2010, in which 25000 households located in ten bairros of the municipal districts of Nhlamankulo and Maxaquene participated, showed only $18 \%$ of the residents used water closet toilets connected to septic tanks. The rest relied either on pour flush latrines [16\%], improved pit latrines [30\%], improved traditional latrines [9\%] or unimproved traditional latrines [24\%] (Muximpua \& Hawkins, 2012). Inadequate on-site sanitation is a major concern for these densely populated settlements, especially for households residing in twelve bairros of Maputo which have a high water table, and are prone to annual flooding during the rainy season (WSUP and SEED, 2011). Yet, Article 89 of the Constitution of Mozambique specifies that each citizen has the right to medical and sanitary services, which should promote and protect public health (WSUP and SEED, 2011).

${ }^{\dagger}$ Source: WSUP and SEED (2011) 
Accordingly, the revised National Water Policy (2007) aims to increase sanitation coverage in the urban areas to at least $67 \%$ of the urban population by 2017 , and advocates for an integrated delivery of water and sanitation services, thereby maximizing hygiene improvements. However, the various state institutions mandated with providing water and sanitation services have not stepped up to the task, leaving huge gaps in service delivery. To fill the gap, various non-state providers are actively involved in providing these services. Non-state providers (NSPs) may be defined as all those individuals and organisations acting otherwise than under the direction of the state. The organisations may be for-profit or not-for profit organisations, NGOs, faith-based organisations and community-based organisations (Wakefield, 2004).NSPs are quite active in provision of water services in Maputo, with about 500 small scale service providers delivering services to 25\% of Maputo's population (Muximpua \& Hawkins, 2012). Also, non-state providers have been actively participating in primary collection of solid wastes in most bairros of Maputo since 2003, through a public private partnership with CMM. This partnership is considered largely effective in the study setting (GIZ, 2012); hence, the authors' position is that this model could be adapted for faecal sludge management. The next sub-section briefly describes the genesis and operationalization of the SWM partnership, so that lessons may be drawn therefrom.

\subsection{Initiation of Public Private Partnerships for primary collection of solid wastes}

Several provinces of Mozambique, including Maputo suffered severe floods in 19992000 which resulted in the displacement of over 500,000 people, and presented a setback in the national economy (USAID, 2002) These floods also exposed CMM's lack of capacity to effectively manage solid wastes, which exacerbated urban flooding. To avert a cholera outbreak, two non-state providers spontaneously emerged in the bairros of Maxaquene and Urbanizacao in 2001, to provide primary solid waste collection services in their localities. Service delivery in these bairros improved tremendously, and, in response to public demand, CMM with the support of the World Bank and the German Gesellschaft für Internationale Zusammenarbeit (GIZ), put mechanisms in place to contract out primary solid waste collection services to community-based organisations and local micro-entrepreneurs in 2003. The main changes initiated in the SWM sub-sector were as follows (GIZ, 2012; Kruks-Wisner, 2006; WSUP, 2011):

1. The legal and institutional frameworks for SWM were clarified, making CMM the lead agency;

2. The legal instruments provided CMM with clear rights and obligations, and spelled out the goals and means to achieve them;

3. Municipal by-laws on SWM were revised to emphasize producer responsibility, participation and the three principles of reusing, recovering and recycling;

4. Various international development agencies provided support in terms of capital development and institutional capacity development (skills training, 
organisational development, institutional strengthening) to the SWM subsector;

5. A study was carried out to establish characteristics of solid wastes (quantities and quality) produced, ability and willingness to pay for services, consumer perceptions etc.;

6. CMM leadership had open discussions on a strategy for improved SWM, with a cost recovery model that incorporated introduction of a waste fee through energy bills, and private sector participation;

7. With the assistance of international development agencies such as GIZ, the capacity of Direccao Municipal de Saude e Saubridada (DMSS), i.e. CMM's Health and Environmental Health Directorate was built, to enable them to develop, monitor and manage service contracts with non-state service providers;

8. Vigorous public awareness and education campaigns were carried out; and

9. CMM monitored the cost recovery model and continuously adjusted the model.

The first waste fee was introduced in February 2002, but was discontinued in J une the same year, due to inadequate public education and involvement. Following the public awareness campaign in 2003, the waste fee was reinstated, with cost recovery rising to about US\$60,000 per month in the same year. The waste fees were gradually increased, and diversified to also cover non-household (commercial, institutional and industrial) premises, which are charged at about twice the household rate, hence providing cross-subsidies to households. As of 2012, annual revenues from the waste fees had increased to about US $\$ 4.1$ million, covering $69 \%$ of the operation and maintenance (O\&M) costs (GIZ, 2012). The balance of the O\&M costs is covered by CMM's general budget.

Table 3: Household tariff structure for SWM in Maputo in 2010 (Source: GIZ, 2012)

\begin{tabular}{|l|c|c|}
\hline Consumption block & Energy consumption per month & Fee (MZN* per month) \\
\hline Social tariff & $0-100 \mathrm{KWh}$ & 10 \\
\hline Low & $101-200 \mathrm{KWh}$ & 35 \\
\hline Medium & $201-500 \mathrm{KWh}$ & 55 \\
\hline High & $>500 \mathrm{KWh}$ & 80 \\
\hline
\end{tabular}

(*At the time of the study 1 US dollar was equivalent to 27 Mozambique Metical [MZN])

Initially, the waste fee was in the form of a flat rate for each household, but since 2007, the waste fee was structured in blocks pegged according to energy consumption per month. The 2010 tariff structure for households is shown in Table 3 . As shown in the table, households which consume up to $100 \mathrm{KWh}$ per month pay a token fee of 10 Mozambique Metical [MZN] (about 0.37 US\$) per month. These households will normally fall into the category of low-income households. This cost recovery model also assumes most households in Maputo city have access to a connection to grid electricity - only the poorest of the poor cannot afford a 
connection. A survey carried in out in 2011/ 12 as part of the 'Home Space for African Cities' study funded by the Danish Research Council found that $75 \%$ of households in the bairros of Maputo had electricity connections (Baptista, 2013). Solid waste collection services to houses without electricity connections are fully subsidised by the state. Electricidade de Moçambique (EDM), the state-0wned electricity service provider, which charges a commission for collecting the SWM fee, is responsible for putting measures in place for recovering costs from non-complying households.

In April 2004, CMM piloted public-private partnerships with two non-state providers for collecting solid wastes from households in their local bairros to secondary storage containers (primary waste collection): Associação da Desenvolvimento da Agua e Saneamento do Bairro de Urbanização (ADASBU), a community-based organisation in the bairro of Urbanização; and Uaene Gama de Serviços de Maputo (UGSM) Lda, a micro-entrepreneur in the bairro of Maxaquene A (Kruks-Wisner, 2006).

SWM services in the bairros are organised on a two-stage collection basis. The contracted non-state providers, who are usually based in the bairros collect the waste from households twice a week and transport it to the secondary storage containers (with capacities ranging between 6-12 cubic metres). These containers are owned by $\mathrm{CMM}$, and are placed in locations that are accessible to collection trucks. These containers are then transported by a private company to the municipal disposal site (GIZ, 2012).

The pilot PPP projects were evaluated and found to be successful, and a year later, these SWM service delivery mechanisms were extended to other bairros, as part of the city's development programme partly financed by the World Bank and international development agencies. By 2006, the level of service for primary solid waste collection in these bairros ranged between $40-75 \%$, compared to the city average of 20\% (Kruks-Wisner, 2006). By 2010, the overall SWM service coverage had improved to $65 \%$, with primary waste collection services provided in all the bairros by 2011 (GIZ, 2012).

\subsection{Institutional framework for urban sanitation services in Maputo}

Figure 2 shows an influence diagram of the urban sanitation institutional framework developed from a review of official documents/ project reports and validated by key informants. Typical of the water and sanitation sectors in many countries of subSaharan Africa, the roles and responsibility for sanitation are spread across many ministries, departments and several tiers of government. At the national level, the lead ministry for the water and sanitation sector is Direcção Nacional de Águas (DNA) i.e. the National Water Directorate of the Ministry of Public Works and Housing. DNA is responsible for policy issues and coordinates all processes concerned with water supply and sanitation services in the country.

Under DNA, the Departamento de Saneamento (DES) i.e. the Sanitation Department is in principle responsible for planning urban and rural wastewater/ on- 
plot sanitation services. DES is comprised of three sections, dealing with (i) management support; (ii) studies and projects; and (iii) evaluation, monitoring and training.

Figure 2: Influence diagram for key agencies involved in urban sanitation in Maputo

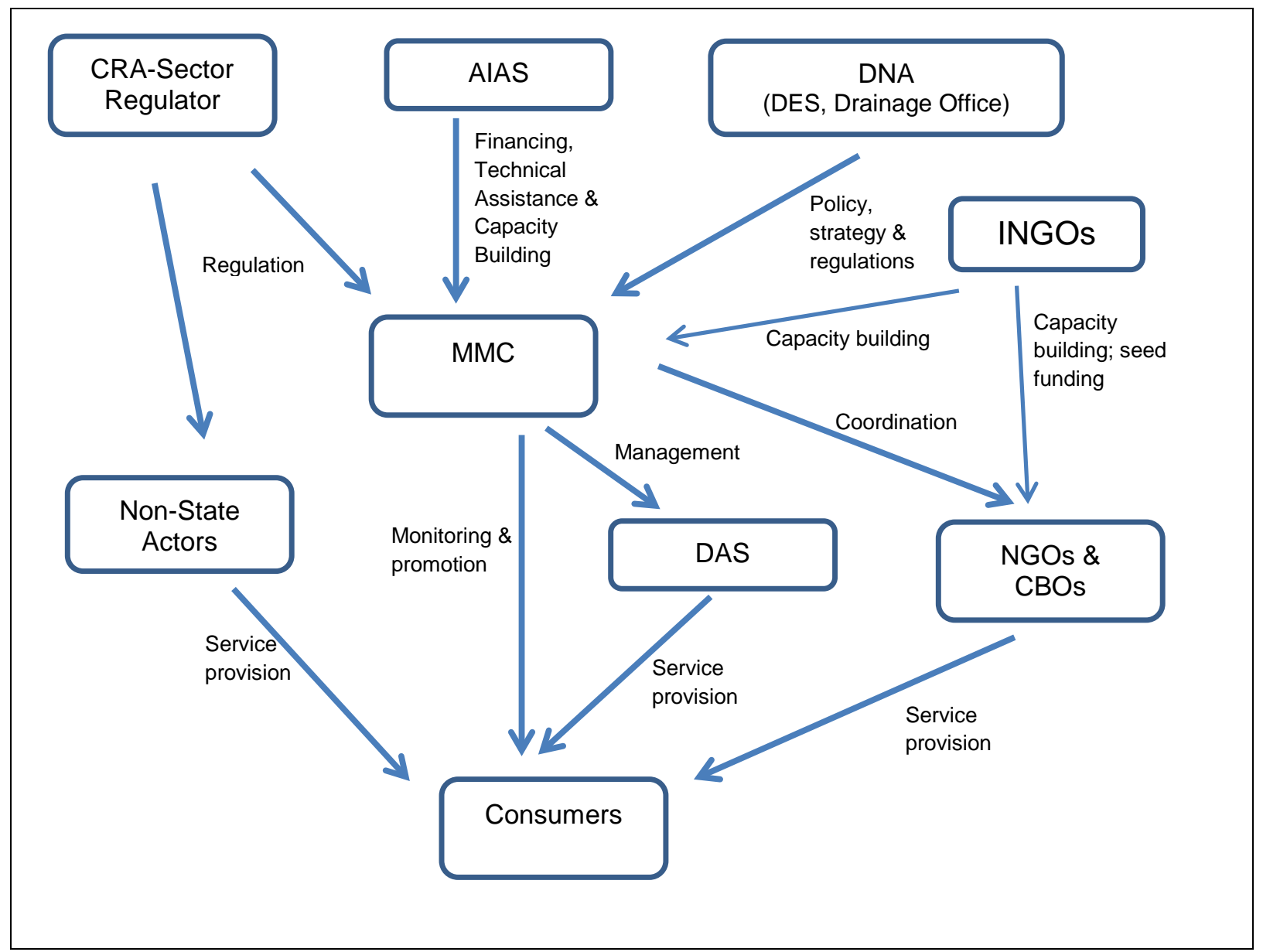

Source: Adapted from Muximpua \& Hawkins, 2012.

Another unit of the Ministry of Public Works and Housing that plays an important role is the Drainage Office of DNA, which regulates the use of wastewater treatment plants that are being operated by Municipal Councils. However, at the time of the study, the Drainage Office was also operating and managing the sewerage network \& sewage treatment plants for System 2 in Maputo, pending transfer to the Municipal Authority. System 2, constructed in the 1980s, is a conventional sewerage system that includes two pumping stations and a wastewater treatment plant at Infulene, which served about 135,000 people by 2006 (WSUP and SEED, 2011). This system was yet to be handed over to the City Municipal Authority of Maputo, reportedly due to lack of institutional capacity at the CMM (ibid, 2011). At the time of the study, Infuleni WWTP was the only legitimate treatment/ disposal facility in Maputo. However, its operation and management is severely inadequate. Faecal sludge is directly discharged into a waste stabilisation pond, with no facilities for sludge drying 
beds. There were no set procedures and systems for managing the discharge of faecal sludge into the WWTP.

A more recent entrant into the sanitation sector arena is the Administraco de Infraestruiras Abastecimento de Agua e Saneamento (AIAS), i.e. the Infrastructure Administration of Water and Sanitation, which was formed as an agency under DNA in 2009. AIAS is a national agency responsible for infrastructure development for sanitation in all urban areas of Mozambique, similar to Fundo de Investimento e Patrimonio de Agua (FIPAG), an asset holding authority for water services in large towns of Mozambique. AIAS is also responsible for water infrastructure development in the smaller towns of the country. At the time of the study, AIAS was still in the setting-up and resource mobilisation stage.

Another important player at the national level of the sanitation sub-sector is the Conselho de Regulacao de Agua (CRA), the Water Regulatory Board. Since May 2009, urban sanitation services have been added to CRA's portfolio. However, at the time of the study, CRA had not yet set up structures and systems for overseeing FSM or any other sanitation-related activities. Other ministries involved in the WASH sector are the Ministries of Health and Environment. The Environmental Health Department of the Ministry of Health is responsible for making policies on water quality and sanitation standards, and providing hygiene education/ sanitation promotion. On the other hand, the Ministry of Environment is responsible for setting policy guidelines for effluent water quality standards.

At the local government level, the municipal/ town councils play important roles in regulating, managing and operating sanitation services in the urban areas. In CMM, the main player is the Departmento de Agua e Saneamento (DAS) i.e. the Department of Water and Sanitation, a department under the Direcção Municipal de Infra Estrutura (DMI) i.e. the Municipal Directorate of Infrastructure. DAS is responsible for managing storm water drainage and wastewater systems owned by CMM, as well as the management of on-plot sanitation systems, such as septic tanks, improved latrines and unimproved latrines. At the time of the study, DAS had two mechanised vacuum emptiers, with capacities of 6,000 and 10,000 litres, respectively, for emptying septic tanks of customers in the well-planned residential areas of Maputo, at a fee. DAS was charging fees equivalent to US $\$ 52.2$ and US\$112.36 for services provided by 6,000-litres and 10,000-litres vacuum tankers respectively. However, these emptiers could not provide services to most parts of the informal settlements, due to lack of access for the trucks and the inability of such trucks to empty pit latrines. Owing to low implementing capacity, DAS provides services in the informal settlements that are limited to overall supervision and enforcement of by-laws, and contracts most activities related to construction, operation and maintenance to local private entrepreneurs and CBOs, such as those listed in Table 1.

Sanitation is of interest to elected civic leaders in the bairros, the lowest administrative level of the city municipality. The secretary of the bairro, an elected 
official, coordinates all development activities in the bairro, and reports to the District Administrator, the top CMM staff that coordinates administrative activities in the municipal district. The elected civic leaders in the bairro form the Bairro Consultative Council, from which several commissions (i.e. committees) are formed to oversee various services, one of which is water and sanitation. At the lower level, the quarteirões, a chief is elected by the residents. The chief coordinates all development activities in the quarteirõ, including water \& sanitation, and reports to the Bairro Consultative Council.

Analysis of the allotment of the responsibilities for sanitation amongst the various government agencies shows that there are considerable gaps and overlaps between policy and practice. Mozambique, like most developing countries in Africa, has low capacity in terms of human resources, mechanisms and systems for effective provision of sanitation (Murungi and van Dijk, 2014). Hence, there are not enough professionals to manage and operate all the functions for effective and efficient service provision in these countries. Enhancement of capacity at the national coordination level can go some way to closing some of the capacity gaps. At the Mozambique national level, there is a proliferation of agencies involved in urban sanitation, and it is not clear which department has ultimate responsibility for coordinating urban sanitation. While the Drainage Office of DNA is responsible for regulation of the use of the wastewater treatment plants, it was also managing and operating one of the systems in Maputo at the time of the study.

Hygiene education and sanitation promotion activities are handled by the Ministry of Health, and there was little evidence of strong collaborative mechanisms between the sector ministries. Although DNA has in the past few years been engaged in decentralisation of operations and management of urban sanitation to the municipalities, the latter have been affected by the inadequate human and physical resources. Furthermore, coordination between the sanitation sector agencies at the national level and the municipal departments responsible for sanitation appear to be weak, leading to fragmentation of interventions by international development agencies - with less gains in scale and scope of impact.

\subsection{Involvement of non-state actors in provision of FSM services}

A number of international development agencies and International Non-Government Organisations (INGOs) provide support for improvement of sanitation services in Maputo in various ways e.g. advocacy, carrying out pilot projects in innovative sanitation delivery mechanisms and/ or supporting community-based organisations involved in the delivery of urban sanitation services. Most of these agencies began their involvement following the floods that affected Maputo in 2000. Examples of organisations that are still active are Care International, WSUP, WaterAid, the Water and Sanitation Programme (WSP) - World Bank and UN-Habitat. INGOs such as WaterAid, WSUP, UNICEF and UN-HABITAT have previously provided capacity building and / or seed funding for CBOs and private entrepreneurs involved in FSM, as briefly described in Table 4. Most of this assistance is time-bound, and at the time 
of the study only WSUP had an active presence in the selected bairros. In response to the flood disaster, a multi-stakeholder working group on sanitation was set up, led by the Department of Water and Sanitation and the Directorate of Environmental Health and Cemeteries, to coordinate emergency sanitation and drainage in the country, especially in Maputo. This working group became inactive in 2004. However, at the time of the study, there was a monthly meeting that brought together agencies and organisations working in water and sanitation, to discuss issues of concern in the sector. This non-statutory group, known as the Group de Agua \& Saneamento (GAS), i.e. the Water and Sanitation Group, aims to make coordinated inputs into sector policy formulation, and its membership includes organisations and agencies such as FIPAG, CRA, DNA, Water Aid, WSUP, WSP, UNHABITAT and UNICEF.

At the service delivery level, a number of community-based organisations and private entrepreneurs provide various types of services along the sanitation service chain. Table 4 briefly describes the characteristics of key providers of sanitation services in the specified informal settlements.

Table 4: Key service providers in selected bairros of Maputo's informal settlements

\begin{tabular}{|c|c|c|c|}
\hline Category & $\begin{array}{l}\text { Service } \\
\text { Provider }\end{array}$ & Brief background & $\begin{array}{l}\text { Sanitation-related services } \\
\text { provided }\end{array}$ \\
\hline \multirow[t]{2}{*}{$\begin{array}{l}\text { Community } \\
\text { based } \\
\text { organisations } \\
\text { (CBOs) }\end{array}$} & $\begin{array}{l}\text { Associação da } \\
\text { Desenvolvime } \\
\text { nto da Agua e } \\
\text { Saneamento } \\
\text { do Bairro de } \\
\text { Urbanização } \\
\text { (ADASBU) }\end{array}$ & $\begin{array}{l}\text { A CBO formed in } 2000 \text { by } \\
\text { residents and community } \\
\text { groups of the bairro of } \\
\text { Urbanização to develop } \\
\text { water and sanitation } \\
\text { services in the } \\
\text { neighbourhood. It was } \\
\text { initially supported by MSF } \\
\text { Belgium, then UNICEF and } \\
\text { UN-Habitat to develop its } \\
\text { capacity. At the time of the } \\
\text { study, it received support } \\
\text { from Apoio a Gestão de } \\
\text { Resíduos Sólidos Urbanos } \\
\text { (AGRESU), a programme } \\
\text { managed by German GIZ, } \\
\text { and WaterAid. }\end{array}$ & $\begin{array}{l}\text { - Contracted by CMM for } \\
\text { primary collection of solid } \\
\text { wastes from households to } \\
\text { secondary storage bins in the } \\
\text { bairros; } \\
\text { - Construction of improved } \\
\text { sanitation facilities; } \\
\text { - Emptying of pit latrines using } \\
\text { the Vacutug } \\
\text { - Managing storage facilities for } \\
\text { holding faecal sludge. } \\
\text { - Transporting faecal sludge to } \\
\text { the disposal plant, including } \\
\text { from neighbouring bairros } \\
\text { - Clearing drainage ditches in the } \\
\text { bairro }\end{array}$ \\
\hline & XIVON & $\begin{array}{l}\text { The second largest CBO } \\
\text { that provides sanitation } \\
\text { services in Hulene B, one of } \\
\text { the bairros of Maputo - } \\
\text { which was mainly } \\
\text { supported by WaterAid. }\end{array}$ & $\begin{array}{l}\text { - Construction of improved } \\
\text { sanitation facilities; } \\
\text { - Emptying of pit latrines using } \\
\text { the Vacutag } \\
\text { - Transporting faecal sludge to } \\
\text { holding tanks operated by } \\
\text { ADASBU. }\end{array}$ \\
\hline $\begin{array}{c}\text { Private } \\
\text { entrepreneu } \\
\text { rs }\end{array}$ & $\begin{array}{l}\text { Uaene Gama } \\
\text { de Serviços de } \\
\text { Maputo } \\
\text { (UGSM) Lda }\end{array}$ & $\begin{array}{l}\text { A private company owned } \\
\text { by Paulino Uaene, a } \\
\text { secondary school teacher } \\
\text { who lived in the bairro of } \\
\text { Maxaquene A. UGSM } \\
\text { started operating }\end{array}$ & $\begin{array}{l}\text { - Contracted by CMM for } \\
\text { primary collection of solid } \\
\text { wastes from households to } \\
\text { secondary storage bins in the } \\
\text { bairros } \\
\text { - Providing solid waste collection }\end{array}$ \\
\hline
\end{tabular}




\begin{tabular}{|c|c|c|c|}
\hline Category & $\begin{array}{l}\text { Service } \\
\text { Provider }\end{array}$ & Brief background & $\begin{array}{l}\text { Sanitation-related services } \\
\text { provided }\end{array}$ \\
\hline & & $\begin{array}{l}\text { informally in Maxequene A } \\
\text { in } 2000 \text {, but was formally } \\
\text { contracted by CMM since } \\
2004 \text { for primary collection } \\
\text { of solid wastes, thereafter, } \\
\text { in 2009, expanding its } \\
\text { services to Maxaquene B. } \\
\text { CARE International and } \\
\text { AGRESU supported its } \\
\text { formation and growth. }\end{array}$ & $\begin{array}{l}\text { services for government offices } \\
\text { and commercial premises in } \\
\text { the central business district of } \\
\text { Maputo } \\
\text { - Health/ hygiene education and } \\
\text { sanitation promotion through } \\
\text { youth theatre groups }\end{array}$ \\
\hline & $\begin{array}{l}\text { Basic } \\
\text { Sanitation for } \\
\text { the } \\
\text { Millennium } \\
\text { (SB } \\
\text { Millennium) }\end{array}$ & $\begin{array}{l}\text { This is a subsidiary } \\
\text { company of UGSM, formed } \\
\text { at the time of the study in } \\
2011 \text { by Paulino Uaene, the } \\
\text { private entrepreneur, to } \\
\text { provide services of } \\
\text { emptying pit latrines and } \\
\text { septic tanks in Maxequene } \\
\text { A and B. The formation of } \\
\text { SB Millennium was } \\
\text { supported by WSUP. }\end{array}$ & $\begin{array}{l}\text { - SB Millennium started } \\
\text { providing emptying services } \\
\text { for pit latrines and septic } \\
\text { tanks, at the end of } 2011, \\
\text { using a combination of } \\
\text { technology options, including } \\
\text { buckets and the 'Gulper' } \\
\text { pump, a low-cost, manually } \\
\text { driven positive displacement } \\
\text { pump (Mikhael et al, 2014) } \\
\text { that mixes up the sludge and } \\
\text { sucks it into containers }\end{array}$ \\
\hline & $\begin{array}{l}\text { Traditional pit } \\
\text { emptiers } \\
\text { (TPE) }\end{array}$ & $\begin{array}{l}\text { These are young men with } \\
\text { age ranging between late } \\
\text { teens to early twenties, who } \\
\text { are loosely connected by a } \\
\text { common trade and - } \\
\text { geographical areas of } \\
\text { operation, with an older } \\
\text { person who acts as a price } \\
\text { estimator/ negotiator. They } \\
\text { work in groups of 2-5, } \\
\text { relying on word-of-mouth } \\
\text { to attract customers }\end{array}$ & $\begin{array}{l}\text { They use manual collection } \\
\text { methods for emptying } \\
\text { traditional, lined/ unlined pit } \\
\text { latrines. }\end{array}$ \\
\hline
\end{tabular}

Most non-state service providers shown in Table 4 operate in the bairro that they originate from, and/ or where their offices are located. Rarely do these providers deliver sanitation services to the neighbouring bairros. All the interviewed representatives of the service providers affirmed their desire and strategic plans to scale up services to other bairros. However, the key informants also spelt out a number of barriers that the non-state service providers are experiencing, which are discussed in the next sub-section.

The main emptying technological options used by the non-state service providers at the time of the study in the bairros are:

- Manual emptying, mainly for traditional (unlined) latrines - this is done by a group of 2-5 young men, by opening the pit and transferring the sludge to

\footnotetext{
${ }^{\ddagger}$ Extra information obtained from Muximpua \& Hawkins (2012)
} 
another hole, which is usually dug within the same plot. They use shovels, buckets and spades. This is usually done at night. Some manual emptiers apply kitchen salt or petrol to reduce the smell, and break down the solidified sludge. The sludge is only transferred from one point to another on the same plot.

- Use of Vacutugs, i.e. small emptiers with the capacity of up to 500 litres (manufactured in Bangladesh with the support of UN-HABITAT) to empty latrines and septic tanks. The vacutugs are mounted on a handcart, which can manoeuvre through the narrow alley ways in the bairros and gain access to most latrines and septic tanks in the informal settlements. Vacutugs experience difficulties in emptying high-viscous sludge, and so water is usually poured in latrines and the sludge stirred up so as to make it more liquid (Mikheal et al, 2014). The sludge is usually transferred to a portable holding tank (e.g. with a 4000-litre capacity) stationed at one point within the bairro, usually at the offices of the community-based organisation involved in latrine-emptying. When the holding tank is full, it will be pulled by a tractor to the dumping site (ideally the wastewater treatment plant). In rare circumstances, the vacutugs may deliver the sludge directly to the dumping site. This is the main emptying technology used by the CBOs active in the bairros of Maputo. All the collection equipment are owned, operated and maintained by the CBOs.

Use of the 'Gulper' pump, a low-cost, manually driven positive displacement pump, was reportedly first deployed by SB Millennium in the bairros of Maputo at the end of 2011, three months after this study (Muximpua and Hawkins, 2012). Hence, its performance was not evaluated during the study.

In the early years of its operations, ADASBU used a sewage suction pump which was fuel-powered, to suck the sludge into a 4000-litre tank pulled by a tractor (Maquineta). This technology was suitable for septic tanks and latrines that could easily be accessed by the tractor. The tank was then pulled to the dumping site (ideally the wastewater treatment plant). This technology was abandoned in 2002, due to the high operational costs associate with it. At the time of the study, the main technology used by ADASBU was the Vacutug.

\subsection{Prices of FSM services provided by non-state providers}

None of the service providers gave an elaborate pricing plan for the charges levied. However, accounts obtained for ADSBU operations in $2006^{\S}$ gave a picture of the proportions of costs incurred by them in providing the service. It shows that about $20 \%$ of the costs were with respect to purchase of fuel and lubricants, $30 \%$ were for maintenance, while $50 \%$ was spent on staff costs. The proportion of the costs for maintenance has gone up as the equipment becomes older. The charges levied by service providers for emptying and transporting are summarised in Table 5. There is

\footnotetext{
${ }^{\S}$ Data provided by WSP-WB, Mozambique country office
} 
only one sludge treatment plant, the Infulene Plant, which was operated by The Drainage Office (DNA) at the time of the study, and it is within 8-12 kilometres of the three study areas. The fee paid by non-state actors to dump faecal sludge at Infulene Plant was quoted as 4000 MZM (US\$150) per month.

The charges levied by CBOs barely cover operation and maintenance costs. These CBOs rely on grants from the national government, international NGOs and other development partners for funding capital expenditure. The major constraint to price levels is balancing with the beneficiary's ability and willingness to pay if the charges are elevated. For instance, a study carried out in the two bairros of Urbanização and Maxaquene A by Building Partnership for Development (BPD) showed that in 2004, $52 \%$ of the owners of on-site sanitation facilities in the bairro of Urbanizacao emptied their own facilities; $30 \%$ hired the services of ADASBU and $18 \%$ hired services of traditional pit-latrine emptiers to carry out the tasks (BPD, 2005).

Table 5: Charges levied by non-state service providers for emptying and/ or transporting septage in the bairros of Maputo, Mozambique

\begin{tabular}{|c|c|c|}
\hline Service Provider & Emptying, transporting \& dumping fee & $\begin{array}{l}\text { Transporting \& } \\
\text { dumping only fee }\end{array}$ \\
\hline $\begin{array}{l}\text { ADASBU charges } \\
\text { in Bairro } \\
\text { Urbanização }\end{array}$ & $\begin{array}{l}200 \text { MZN (US\$7.5) for } 500 \text { litres (vacutug) } \\
1000 \text { MZN (US\$37.5) for } 4000 \text { litres } \\
\text { (Maquineta) }\end{array}$ & \\
\hline $\begin{array}{l}\text { ADASBU charges } \\
\text { in neighbouring } \\
\text { bairros }\end{array}$ & $\begin{array}{l}350 \text { MZN (US\$13) for } 500 \text { litres (vacutug) } \\
1500 \text { MZN (US\$ 55.6) for } 4000 \text { litres } \\
\text { (Maquineta) }\end{array}$ & $\begin{array}{l}800 \mathrm{MZN}(\mathrm{US} \$ 30) \text { for } \\
\text { transporting from } \\
\text { XIVONINGO offices to } \\
\text { Infulene WWTP }\end{array}$ \\
\hline $\begin{array}{l}\text { XIVONINGO } \\
\text { charges in Hulene } \\
\text { B }\end{array}$ & 300 MZN (US\$11.2) for 500 litres (vacutug) & \\
\hline $\begin{array}{l}\text { Traditional pit } \\
\text { latrine emptiers - } \\
\text { manual }\end{array}$ & \multicolumn{2}{|c|}{$\begin{array}{l}\sim 300 \text { MZN (US\$11.2) for } 210 \text { litre oil drum } \\
\sim 500 \text { MZN (US } \$ 18.7 \text { ) for an improved latrine 1.5m diameter x 1.5m deep- } \\
\text { The sludge is scooped out using buckets and shovels and carried to a new } \\
\text { pit dug within the plot. The fee is inclusive of charges for digging new pit. }\end{array}$} \\
\hline
\end{tabular}

\subsection{Challenges faced by non-state FSM service providers in the bairros}

One of the key challenges faced by the non-state FSM service providers in Maputo is over-reliance on INGOs for financing of capital costs, and, for some service providers, a proportion of operating costs as well. This brings into focus the question of financial sustainability of FSM services by non-state service providers in the current institutional and policy environment. Other operational challenges faced by the nonstate providers of sanitation services may be classified according to the various stages of the sanitation value chain, as detailed below. 


\subsubsection{Emptying/desludging the latrines}

Invariably, the service providers face challenges of accessing the latrines, due to space limitations in the informal settlements. Conventional vacuum tankers mounted on trucks, which are owned and operated by CMM cannot be used in the high-density informal settlements. Also, the costs for emptying latrines using mechanical emptiers are unaffordable to many households in the informal settlements, and so they mainly rely on TPEs. TPEs descend into the pits and manually scoop the faecal sludge using buckets. The faecal sludge is then transferred to another pit which has been dug nearby in the compound. Owing to the land shortage in informal settlements, it is becoming increasingly challenging to get space for containing the faecal sludge. Furthermore, many traditional latrines are unlined and unsafe to empty. Also, TPEs lack safety equipment and work in unhygienic and unsafe condition. Socially, the work of TPEs is perceived as undignified and demeaning, and these services are usually provided under the cover of darkness.

Other service providers use emptiers of a smaller capacity, which are usually mounted on handcarts, so as to manoeuvre through the informal settlements. From around 2001, ADASBU was emptying toilets using a fuel-powered pump (i.e. the Maqunieta), which sucks the faecal sludge into a 4,000-litre tank pulled by a tractor. This method could only work for low-density, fairly planned settlements. In order to reach more latrines in the area, and extend emptying services to the neighbouring bairros, ADSBU started using the vacutug in 2003. There are several challenges that have been experienced with the use of the vacutug:

- Vacutugs do not have enough suction power to remove the heavier, more compacted faecal sludge at the base of latrine pits. In many cases, even attempts to mix the faecal sludge with water have not yielded positive results.

- The Operation and Maintenance (O\&M) costs of vacutugs are reportedly high, especially as they approach their economic life.

- The newer generation of vacutugs which are being assembled in a developing country are reportedly more costly in terms of O\&M costs.

\subsubsection{Conveyance to secondary storage and/or final treatment/disposal site}

At the time of the study, only ADASBU had a 4000-litre faecal sludge holding tank, located at its offices, which was also shared with XIVONINGO, the CBO offering emptying services in Hulene-B. As the services expanded, the capacity of the tank became inadequate. Initially, vacuum tankers operated by the municipality regularly transported the faecal sludge from the holding tank to Infuleni Wastewater Treatment Plant (WWTP). The vacuum tankers become unreliable and ADASBU was forced to buy a tractor for hauling the tank to the WWTP. The WWTP is located $9 \mathrm{~km}$ from the city centre, which affects the fuel/ lubricants and maintenance costs accounting for about $50 \%$ of the total service costs. Not only is this mode of transport too costly for the service providers, but the tractor operators find it onerous, timeconsuming and inconvenient to other road users. 


\section{CONCLUSIONS}

Most residents of urban areas in developing countries rely on on-plot sanitation facilities (Baum et al, 2013). This situation in developing countries is not about to change, given the various structural and non-structural barriers that hinder effective provision of sanitation services in urban areas. In recognition of this situation, there has been a renewed effort to develop systems, mechanisms and incentives for effective faecal sludge management in urban areas. This paper reports on a study conducted in three out of 54 bairros in Maputo, which were selected to represent a typical situation in the informal settlements of Maputo.

Non-state providers, i.e. CBOs and local micro-entrepreneurs supported by international development agencies are playing an important role in improving FSM services in these low-income settlements of Maputo. However, these interventions have not created as large an impact on service coverage as what has happened in the solid waste management (SWM) sector, where primary solid waste collection in the bairros of Maputo and other parts of the city has tremendously improved. SWM and FSM have many similarities, an important one being that both are a responsibility of CMM. This paper advocates that public-private partnership framework put in place for SWM be adapted for FSM in low-income settlements of Maputo. To push the envelope of on-plot sanitation services in Maputo, there is a need to analyse and identify the key success factors in SWM and adopt the lessons for FSM.

Key lessons from SWM that could be adapted for FSM are listed below (KruksWisner, 2006; GIZ, 2012):

1. Fast-tracking the study already started on development of a holistic and integrated approach to sanitation planning, taking into account the existing situation, current actors and the desired situation.

2. A detailed analysis of the financing model for sanitation services, highlighting finance gaps for acceptable service delivery levels, and what combinations of options are available for closing the gaps.

3. Developing the institutional capacity of the DAS to coordinate various actors in the sanitation sector.

4. Carrying out a study to assess the households' need for improved sanitation services and their capacity and willingness to pay for better services. This should be combined with a public sanitation promotion and hygiene awareness campaign.

5. Studying the existing legal framework and making amendments that will clarify roles and responsibilities for FSM, and create a conducive enabling environment for public-private partnerships in service delivery.

6. More constructive engagement between the various non-state providers and CMM on public private partnerships. This engagement should build on the existing arrangements in some bairros and scale out to other neighbourhoods. 
Subject to limitations of the case study methodology, these lessons have implications for policy and practice in Maputo and cities of other developing countries.

\section{ACKNOWLEDGMENTS}

The funding for this study was provided by Bill and Melinda Gates Foundation, and the research consortium was managed by Water and Sanitation for Africa (WSA). We are grateful to all stakeholders in Maputo who freely provided the necessary information.

\section{REFERENCES}

Baptista, I. (2013) Everyday practices of prepaid electricity in Maputo, InSIS Working Paper Series, Institute for Science, Innovation and Society, University of Oxford, UK.

Baum, R., Luh, J . and Bartram, J . (2013) Sanitation: A global estimate of sewerage connections without treatment and resulting impact on MDG progress, Environmental Science and Technology, 2013, 47 (4), pp 1994- 2000.

Building Partnerships for Development (BPD) (2005) Sanitation Partnerships: Maputo Case Study, London.

Gesellschaft für Internationale Zusammenarbeit (GIZ) (2012) Economic Instruments in Solid Waste Management: Case Study Maputo, Mozambique, German Federal Ministry for Economic Cooperation and Development, Bonn.

Kayaga, S (2013) Effective Water Safety Management of Piped Water Networks in Low-income Urban Settlements, J ournal of Water, Sanitation and Hygiene for Development, 3(3), pp.402-410.

Kruks-Wisner, G. (2006) After the Floods: Crisis, Voice and Innovation in Maputo's Solid Waste Management Sector, Master in City Planning Dissertation, Massachusetts University of Technology, USA.

Leach, M., Scoones, I. \& Stirling, A. (2010) Dynamic Sustainabilities: Technology, Environment, Social J ustice. Earthscan, London.

McConville, J . Kain, J ., Kvarnström, E. and Renman, G. (2011) Bridging sanitation engineering and planning: theory and practice in Burkina Faso, J ournal of Water, Sanitation and Hygiene for Development, 1(3), pp. 205-212.

Mikhael, G., Robbins, D.M., Ramsay, J.E. and Mbeguere, M (2014) Methods and means of collection and transport of faecal sludge, in Strande, L., Ronteltap, M. and Brdjanovic, D. (eds) Faecal Sludge Management: Systems Approach for Implementation and Operation, London: IWA Publishing. 
Murungi, C. and van Dijk, M.P. (2014) Emptying, transportation and disposal of faecal sludge in informal settlements of Kampala Uganda: The economics of sanitation, Habitat International, 42, pp.69-75.

Muximpua, O and Hawkins, P. (2012) Building blocks for effective faecal sludge management in peri-urban areas: the role of small scale service providers in Maputo, Second International Faecal Sludge Management Conference, 29-31 October 2012, Durban, South Africa.

Scott, P., Cotton, A. and Sohail Khan, M. (2013) Tenure security and household investment decisions for urban sanitation: The case of Dakar, Senegal, Habitat International, 40, pp.58-64.

Taing, L., Pan, S., Hilligan, J ., Spiegel, A. and Armitage, N.P. (2013) Challenges facing sanitation-provision partnerships for informal settlements: a South African case study, J ournal of Water, Sanitation and Hygiene for Development, 3(2), pp. 230-239.

Tiberghien, J .E., Robbins, P.T. and Tyrrel, S.F. (2011) Reflexive assessment of practical and holistic sanitation development tools using the rural and peri-urban case of Mexico, J ournal of Environmental Management, 92(3), pp. 457- 471

Tilley, E., Bieri, S. and Kohler, P. (2013) Sanitation in developing countries: a review through a gender lens, J ournal of Water, Sanitation and Hygiene for Development, 3(3), pp. 298-314.

UN-HABITAT (2003) Slums of the World: The Face of Urban Poverty in the New Millennium, UN-HABITAT, Nairobi.

UN-HABITAT (2011) Cities and Climate Change: Global Report on Human Settlements 2011, UN-HABITAT, Nairobi.

UN-HABITAT (2013) Planning and Design for Sustainable Urban Mobility, UNHABITAT, Nairobi.

U.S. Agency for International Development (USAID) (2002) Mozambique 19992000 floods: Resettlement Grant Activity, available at http:// www.sarpn.org/documents/d0000811/P907-Mozambique floods 19992000 USAID 072002.pdf, accessed on 6 J anuary 2015.

Water and Sanitation for Africa (WSA) (2012) Benchmarking of urban sanitation pricing and tariff structure in Africa - Consolidated Report, available at http:// www.pseau.org/outils/ouvrages/ eaa_benchmarking_of_urban_sanitation_p ricing_and_tariffs_structure_in_africa_2013.pdf, accessed on 6 J anuary 2015.

WHO/ UNICEF J oint Monitoring Programme (2013) Progress on Sanitation and Drinking Water, 2013 Update, World Health Organization and UNICEF, Geneva. 
Water \& Sanitation for the Urban Poor (WSUP) and Socieda de Engenharia e Desenvolvimento Lda (SEED) (2011) Formulation of an outline strategy for Maputo City citywide sanitation planning - Final Report, Maputo.

Wakefield, E. (2004) Mapping of donors' policies and approaches towards non-state service providers, IDD, University of Birmingham, available at http:// www.bpdwaterandsanitation.org/ bpd/ web/ d/ doc 179.pdf?statsHandlerDone=1 (accessed on $4 \mathrm{~J}$ an 2015).

Water and Sanitation Program (WSP) (2013) Poor-Inclusive Urban Sanitation: An Overview - Targeting the Urban Poor and Improving Services in Small Towns, Study No. 80347, The World Bank, Washington DC.

World Bank (2003) Efficient, Sustainable Service for All? An OED Review of the World Bank's Assistance to Water Supply and Sanitation. Operations Evaluation Department, The World Bank, Report No. 26443. 


\section{Annex 1: Interview Guide for Traditional Pit-Latrine Emptiers}

- Are they from the bairro that they operate in?

- Who do they usually work for (family?)

- Do they work independently or for someone?

- What are the general process for emptying / transport / disposal - operational approach (alone, two, three? Why?).

- Disposal routes - where do they get rid of sludge? Why? Are there any alternatives? What motivation needed to look at alternatives, e.g. composting?

- Charges; what determines cost; how is payment done (up front or staged?)

- How many pits / tanks emptied per week/ month?

- Usual contents of the pit

- Do they also build latrines?

- What sort of pits will they / won't they empty? Are there pits that are easier / impossible to empty? Why?

- Do they just do pit-emptying or doing something else to make a living as well? Are they making a significant profit from pit-emptying?

- Is there anything they don't like about the way they operate? What \& why? How do they see it could be improved? Any interest in alternatives to manual emptying?

- Does an association exist (pit emptiers , community based, formal/informal?)

- How do they think the business could be improved? 